\title{
The Development of English Learning Model in Primary School Based on Local Wisdom of Buton
}

\author{
Nur Dahniar ${ }^{1 *}$, Cecep Nuryadin ${ }^{1}$, Andi Lely Nurmaya ${ }^{1}, \operatorname{Irsan}^{1}$ \\ ${ }^{1}$ Muhammadiyah University of Buton, Baubau, Indonesia \\ *Corresponding author. Email: nurdahniar.powerbuttonqueen@gmail.com
}

\begin{abstract}
This study aims to create an English language learning model based on local wisdom of Buton in elementary schools. This research is descriptive qualitative research that aims to design a conceptual model of learning English based on local wisdom. This study used primary school population in Betoambari District, Baubau City, Southeast Sulawesi Province, and the sampling technique is done by using a multi-stage sampling technique. Data were collected using a questionnaire, document analysis and supplemented with interviews. The data obtained is a conceptual model of English learning that contains basic standards competency in elementary schools, basic competencies, themes/materials that need to be taught to achieve competencies, approaches, methods/strategies, and assessments used to assess student competencies in learning English. This model will be the basis for developing modules and tools for learning English elementary schools based on local wisdom of Buton.
\end{abstract}

Keywords: English language, local wisdom, learning

\section{INTRODUCTION}

The teaching material development in the form of module is a set of procedure conducted to develop module learning system. A certain procedure is needed in developing module that is appropriate to the goal, clear learning content structure and fulfilled valid criteria for learning development. There are five criteria in module arrangement, they are: a) to help students in preparing independent learning, b) to have learning plan that can be responded maximal, c) to load complete learning content and able to give learning chance to the students, d) can monitor student's learning activity, and e) can give suggestion, instructions and information for improving student's learning. Theory and model of learning planed should show three main components: a) learning condition, b) learning method, and c) learning result. The material that will be developed in teaching material in the form of module is descriptive text. Descriptive text is the writing strategy to describe "something", so the readers can feel what writer feel.

The problem gained of descriptive text material has not reached yet the maximal result, that has reached yet minimum criteria of mastery learning. This is supported by interview result that researcher did with English teacher in SD Negeri 1 Bone-Bone, Baubau City, it gains data that learning result of writing descriptive text has not reached minimum criteria of mastery learning 66,75. Further descriptive text material that is used by student, its result is that teaching material of descriptive text on the textbook used is limited and not contextual. Descriptive text on textbook only discuss some culture, so it is not appropriate to culture that exist in each region. To fix the limitation of lack of teaching material on the textbook, teacher is needed in developing module because teacher is given freedom to develop their teaching material.

One of local wisdom that is become in learning for $\mathrm{V}$ grade students of SD Negeri 1 Bone-bone is found on Butonese symbol. The symbol has motto "Momini Sarewhu Mia mo Adhari Ngkita Yindamo lawana Taadari Karota" that means "everything starts from our motivation". The other meaning this motto is repairing based on each field/function and ability. Students can also build their character through local wisdom. This is explained in Sibarani [14] at comprehension about local wisdom concept is needed, so it is stated in managing social life. The other function of local wisdom is the application in forming young generation characters as socio-cultural capital, especially two prosperity improvement of next generation. For peace purpose, local wisdom functions as goodness source in interaction, so it is peace in the interaction while for prosperity, local wisdom functions as creativity source, cultural industry deposit, and success motivation for prosperity of society, two aims of local wisdom finally function to form young generation characters that own personality and character that love to peace and prosperity. Local wisdom function as good personality and character formation especially for V grade SD Negeri 1 Bone-Bone to organize thinking way and act in the life. So that the local culture must survive, the students are considered as the next generation needed given love to local culture especially in region. one of ways that can be given is by integrating local culture values in learning process, especially in descriptive text and student can describe directly either oral or written to object or local culture of Buton so that it can preserve the region concretely in learning. 


\section{LITERATURE REVIEW}

\subsection{Module}

Prastowo [13] defines that module is as printed based one of teaching material forms arranged for learning independently by the students. Therefore, module is completed with instruction for learning individually. Students can learn by themselves without teacher directly. Hamdani [7] defines "module is tool of learning that consist of material, method, limitation of learning material, learning activity instruction, exercise and evaluation way arranged systematically and attractively to gain hoped competency and can be used independently."

National Education Department in the book Learning Technique with Module defines that module is as a unit of learning material presented in form of "self-instruction". It means learning material arranged in the module can be learnt by students independently with limited help from teacher and the other people, so it can conclude that module is a smallest and planned program of learning teaching that is learnt by student individually, because module is a unite that stands alone and consist of a series leaning activity arranged to help students to gain amount of aim formulated specially and clearly. Next, module learning is stated by Sani that independent learning process about a unit of certain discussion by using teaching material arranged systematically, operationally and directed to be used by students, and by using guidance for teacher. Module can be formulated as complete unit that stands alone and consists of a series of learning activity arranged to help students to gain the aim formulated specially and clearly.

Based on the definition above, it can be concluded that module is teaching material arranged systematically that consists of material, method, border of learning material, learning activity, exercise and evaluation ways that can be used by students.

Attitude is someone's belief about giving basic to someone to respond or have attitude in certain way. Attitude is mental readiness that takes place in one's self with the experience, give direction and decide respond to various objects and situations. Attitude contains three components that form attitude structure. Three components are presented as follows: (a) Cognitive component (perceptual component), is the component related to science, views, belief. This component relates to how someone has perception of attitude object. b) Affective component (emotional component), is the component related to happiness or unhappiness of attitude object. Happiness is positive thing while unhappiness is negative thing. This component shows positive and negative attitude. c) Conative component (behaviour component) is the component that tends to act to attitude of object. This component shows intensity of attitude to show how big and small tendency in acting or having attitude to attitude of object.

\subsection{Descriptive Text}

Curriculum 2013 is curriculum of text-based learning. One of them is descriptive text or the previous curriculum that is more famous on paragraph. Both consist that as if readers can see, hear or feel what is written by writer. According to Daryanto [5] the type of text that function to describe object as clear as it, so as if readers or listeners can see the object while Fajarini [6] explains that descriptive text is text that contains impression about what it observed through five senses, so as if readers see and feel an object overall as experienced by writer. So, it can conclude that descriptive text is the text that contains a series of a clear and detailed object or event, so as if reader joins in it. Depdiknas [3] structure part of descriptive text is arranged as follows. The explanation of draft above is as follows: (a) identification is feature, sign, and that is on the text; (b) definition is the grouping based on types or group; and (c) description is about images in the text.

The language element in descriptive text learning is referred word and grouping word. Referred word is one word referring to other word show relation. Referred word relates to pronoun. Affix is base word that gets prefix, suffix and infix. Grouping word is a group of word in the descriptive text.

\subsection{Local Wisdom}

Local wisdom can be comprehended as human's effort by using his cognitive to act and has attitude to an object or event in certain room. Hartono [8] the definition is arranged where wisdom is understood as ability in using his mind in acting and having attitude as assessment result to an object or happened event. The concept of local wisdom in live environment is explained by Dahliani \& Ispurwono [4] with terminology of traditional ecology science. The term means a group of science, practice and the conviction develop through adaptive process that is passed from generation to generation through culture, related to relation between human and environment. Traditional ecology science is owned collectively and can be conveyed in the form of story, song, culture value, belief, ritual, custom law, local language and natural resources function.

\section{METHOD}

Type of this research is research and development known as (R\&D), it is local wisdom of Buton of teaching material development of descriptive text for $\mathrm{V}$ grade SD Negeri 1 Bone-Bone. This subject consists of 3 students with individual trial, 9 students with small group trial, and 35 students with limited field trials. Technique of data collection uses observation, interview, questionnaire, and writing descriptive text test. 


\section{RESULTS AND DISCUSSION}

\subsection{Teaching Material Plan}

The process of teaching material plan is collecting information. The conducted introduction research is by surveying (analysis need) and surveying literature. The result of the distributed questionnaire to teachers and students get the conclusion as follows.

a. Some teachers $(50 \%)$ state that they have not known yet developed teaching material while all students $(100 \%)$ state that they have not yet developed teaching material.

b. All teachers $(100 \%)$ state that they have used yet developed teaching material in learning process and $100 \%$ students state that they have used yet the developed teaching material based on curriculum 2013.

c. All teachers $(100 \%)$ state that they need developed teaching material based on curriculum 2013 in learning process and some of students $(100 \%)$ state that they need developed teaching material-based experience in learning process.

The next step is literature survey. The result of literature survey is gained while teaching material used by English teacher of V grade of SD Negeri 1 Bone-Bone is teaching material produced by Culture and Education Ministry titled "English" Curriculum that is run right now is curriculum 2013 that is revised in 2016.

\subsection{The Beginning Product Development}

The step of beginning product development undertaken is validation of material content and learning design, product revision, and conduct of values and suggestion by teacher. The beginning product from developed teaching material is teaching material in the form of module in descriptive text material of local wisdom of Buton for $\mathrm{V}$ grade as follows: 1) Preference; 2) Content; 3) Concept map; 4) Introduction; 5) Learning Activities 1,2 and 3. (1) Learning activity 1 (Introduction, Definition of descriptive text, Structure of descriptive text, the principle of descriptive text, Steps of writing descriptive text, the example of descriptive text, summary, exercise, and key answer). (2) Learning activity 2 (Introduction, constructing descriptive text context, Comprehending principle of descriptive text, summary, exercise). (3) Learning activity 3 (Introduction, types of descriptive text, Local wisdom of Buton, the example of descriptive text, summary and exercise); 6) Evaluation; 7) Answer keys; 8) glossaries; and 9) References.

The next step of developed teaching material is validated by material expert team, design team, response of an English teacher and student. The result of teacher's response to local wisdom of Buton based teaching material of descriptive text developed has average $88,33 \%$ on "very good" criterion. This means that teaching material in the form of local wisdom of Buton based module of descriptive text developed can fulfil the demand of learning need that will be taught to $\mathrm{V}$ grade students. The result of teaching material expediency will be described as follows a. Content Expediency. Content expediency consist of four sub components: a) the expediency of material of core competency and base competency, b) material accurateness, c) the update material and d) supporting desire. The assessment result on sub component of the expediency of material of core competency and base competency is stated "very good" with total percentage $91,67 \%$. The assessment result on sub component of material accurateness is stated "very good" with the total percentage $91,07 \%$. The assessment result on sub component of the update material is stated "very good" with the total $85 \%$. The assessment result on sub component of supporting desire is stated "very good" with the total $81 \%$. The average of whole content expediency is stated "very good" with the average $88.24 \%$.

b. Presenting Expediency. Presenting expediency consist of three sub components such as: a) presenting technique, b) presenting of learning, and c) presenting complete. The assessment result on sub component of presenting technique is stated "very good" with the average $81.25 \%$. The assessment result on sub component of presenting of learning is stated "very good" with the average $83.33 \%$. The assessment result on sub component of presenting completeness is stated "very good" with the average $91 \%$. The average of presenting expediency is stated "very good" with the average $87.50 \%$.

Language assessment. Language assessment consist of sub components such as a) clear, b) communicative, c) dialogic and interactive, d) suitability to student's development stage, e) stages and unification of thinking, and f) the using of terms, symbol, and icon. The assessment result of sub component of clear is stated "very good" with the percentage $83.33 \%$. The assessment result of sub component of communicative is stated "very good" with the percentage $81.25 \%$. The assessment result of sub component of dialogic and interactive is stated "very good" with the percentage $94 \%$. The assessment result of sub component of suitability to student's development stage is stated "very good" with the percentage $100 \%$. The assessment result of sub component of stages and unification of thinking is stated "very good" with the percentage $81 \%$. The assessment result of sub component of the using of terms, symbol, and icon is stated "very good" with the percentage $88 \%$. The average of whole language assessment is stated "very good" with the percentage $87.50 \%$.

Graphic Expediency. Graphic expediency consists of three sub components such as a) teaching material size, b) cover design of teaching material, and c) content design of teaching material. The assessment result on sub component of teaching material size is stated "very good" with the percentage $93.75 \%$. The assessment result on sub component of cover design of teaching material is stated "very good" with the percentage $90 \%$. The assessment result on sub component of content design of teaching material is stated "very good" with the percentage $91 \%$. The average of whole graphic expediency is stated "very good" with percentage $91.25 \%$. 


\subsubsection{Post-test}

Student's learning result (post-test) can be seen on the table as follows:

Table 2 Student's Post-test Data

\begin{tabular}{|lccc|}
\hline \multirow{2}{*}{ Data Source } & \multicolumn{3}{c|}{ Score } \\
\cline { 2 - 4 } & Min & Max & Mean \\
\hline Experiment Class & 60 & 92 & 75.37 \\
Control Class & 60 & 87 & 69.85 \\
\hline
\end{tabular}

Based on the table above, it explains that after conducting learning by using teaching material of local wisdom of Buton based descriptive text on experiment class and textbook that is usually used in the school on the control class gain the average for experiment class 75.37 and for control class 69.85 . from the assessment result above, experiment class that uses teaching material of local wisdom of Buton based module of descriptive text material gets the higher average that control class.

\subsubsection{Learning result}

Before conducting learning, process using local wisdom of Buton based teaching material of writing descriptive text, Pre-test is conducted first either in experiment class or control class. The aim of pre-test is to know that the average of student's ability between experiment class and control class.

Table 1 Student's Pre-test Data

\begin{tabular}{|lccc|}
\hline \multirow{2}{*}{ Data Source } & \multicolumn{3}{c|}{ Score } \\
\cline { 2 - 4 } & Min & Max & Mean \\
\hline Experiment Class & 40 & 65 & 63.69 \\
Control Class & 44 & 68 & 64.03 \\
\hline
\end{tabular}

Based on the table above, the experiment and control class have the average that is not quite different. The average score of experiment class is 63.69 and the average score of control class is 64.03 . Based on the average of pre-test data of students above, it can be concluded that experiment class and control class have the same ability.

\subsubsection{The learning implementation of using local wisdom of Buton based teaching material of writing descriptive text}

The learning implementation of experiment class takes place three meetings following learning schedule that is decides by school. The learning is undertaken for two hours and undertaken 3 days based on provided base competency. As long as Three days students are focused using local wisdom of Buton based teaching material in module of descriptive text material that has been prepared. Each student gained the same material. The learning process of experiment class uses local wisdom of Buton material module of descriptive text and control class uses textbook that is used every day.

\subsubsection{The difference of learning result of experiment class and control class}

After getting learning by using local wisdom of Buton based teaching material in the form of descriptive text module, students' learning result in the experiment class experiences the significant improvement while in the control class the students get little improvement. The average of experiment class pre-test get 63.65 and average score of post-test 75.37 that there are learning result improvement that is 11.72 while in the control class gets 64.45 for pre-test and 69.85 for post-test that means that there learning improvement 5.4 .

\section{ACKNOWLEDGMENT}

This research was supported by University of Muhammadiyah Buton We thank Mrs. Waode Al Zarliani our Rector for supporting us, and Mr. Hardin and Mr. Cecep colleagues from LPPM who provided insight and expertise that greatly assisted the research, although they may not agree with all of the interpretations of this paper. We thank Mrs. Nazriani for assistance and for comments that greatly improved the manuscript.

\section{REFERENCES}

[1] Albertus, Doni Koesoema. (2007). Pendidikan Karakter, Strategi Mendidik Anak di Zaman

[2] Borg and Gall. 1983. Qualitative Research, Techniques And Procedures For Developing Grounded 
[9] Hermenita, Reszy Yuli \& Yuli Tiarina. 2013.

Theory, Sage Publications, International Educational And Profesional Publisher. London.

[3] Depdiknas. 2002. Teknik Belajar dengan Modul. Jakarta: Dirjen Pendidikan Dasar dan Menengah.

[4] Dahliani \& Ispurwono. 2015. Local Wisdom in Built Environment in Globalization Era. International Journal of Education and Research Vol. 3 No. 6 June 2015.

[5] Daryanto. 2013. Menyusun Modul: Bahan Ajar untuk Persiapan Guru dalam Mengajar. Yogjakarta: Gavamedia.

[6] Fajarini. 2014. Peranan Kearifan Lokal dalam Pendidikan Karakter. Jurnal Sosio Didaktika: Vol. 1, No. 2 Desember 2014.

[7] Hamdani. 2011. Strategi Belajar Mengajar. Bandung: Pustaka Setia.

[8] Hartono, Bambang. 2011. Handout Perkuliahan Telaah Buku Teks. Semarang: Jurusan Bahasa dan Sastra Indoensia.
Teaching Writing A Descriptive Text By Using

Environmental Observation Strategy. Journal of English Language Teaching, Vol. 1 No. 2, September 2013, Serie A.

[10] Kemendikbud. 2013. Buku Paket Siswa Bahasa Indonesia Kelas VII. Jakarta. Menteri Pendidikan dan Kebudayaan.

[11] Mulyadi, Yadi. 2013. Bahasa Indonesia untuk SMP-MTS Kelas VII. Bandung: Yraima Widya.

[12] Putra, N. 2012. Research \& Development Penelitian dan Pengembangan: Suatu Pengantar. Jakarta: Rajawali Pers.

[13] Prastowo, Andi. 2015. Panduan Kreatif Membuat Bahan Ajar Inovatif. Jogjakarta: Diva Press.

[14] Sibarani, Robert. 2012. Kearifan Lokal. Jakarta: Asosiasi Tradisi Lisan (ATL). 